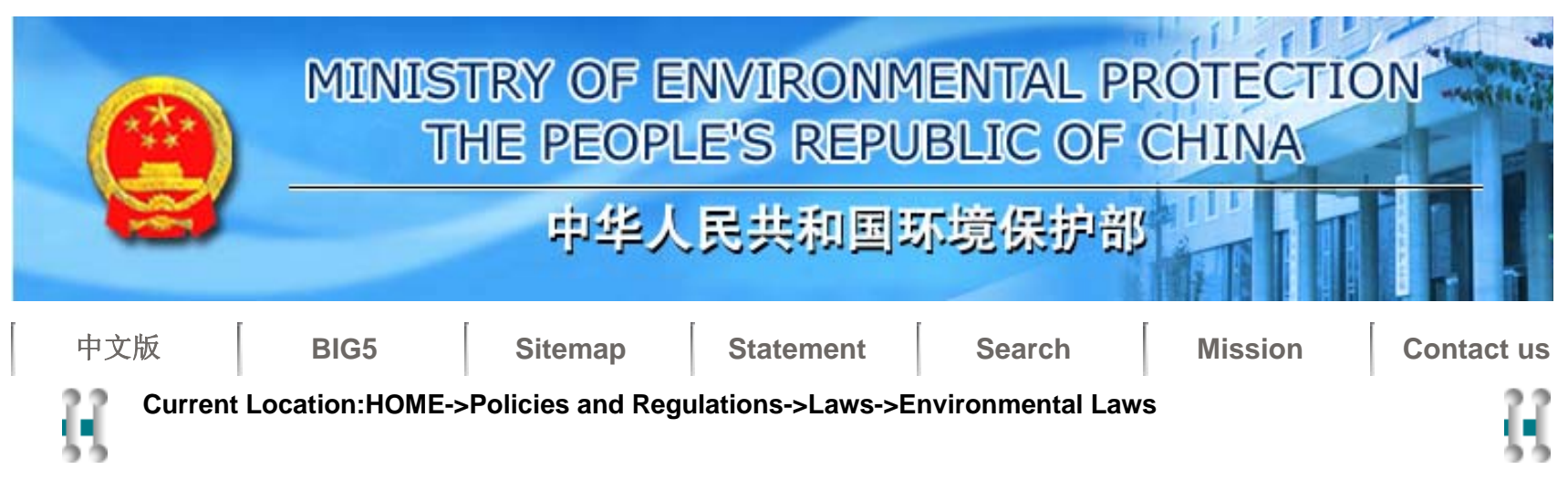

\title{
Environmental Protection Law of the People's Republic of China
}

$1989-12-26$

Article type: Redistributed

(Adopted at the 11th Meeting of the Standing Committee of the Seventh National People's Congress

on December 26, 1989, promulgated by Order No. 22 of the President of the People's Republic of China

on December 26, 1989 and effective on the date of promulgation)

\section{CHAPTER I GENERAL PROVISIONS}

Article 1 This Law is formulated for the purpose of protecting and improving People's environment and the ecological environment, preventing and controlling pollution and other public hazards, safeguarding human health and facilitating the development of socialist modernization.

Article 2 "Environment" as used in this Law refers to the total body of all natural elements and artificially transformed natural elements affecting human existence and development, which includes the atmosphere, water, seas, land, minerals, forests, grasslands, wildlife, natural and human remains, nature reserves, historic sites and scenic spots, and urban and rural areas.

Article 3 This Law shall apply to the territory of the People's Republic of China and other sea areas under the jurisdiction of the People's Republic of China.

Article 4 The plans for environmental protection formulated by the state must be incorporated into the national economic and social development plans; the state shall adopt economic and technological polices and measures favourable for environmental protection so as to coordinate the work of environmental protection with economic construction and social development.

Article 5 The state shall encourage the development of education in the science of environmental protection, strengthen the study and development of the science and technology of environmental protection, raise the scientific and technological level of environmental protection and popularize scientific knowledge of environmental protection. 
Article 6 All units and individuals shall have the obligation to protect the environment and shall have the right to report on or file charges against units or individuals that cause pollution or damage to the environment.

Article 7 The competent department of environmental protection administration under the State Council shall conduct unified supervision and management of the environmental protection work throughout the country.

The competent departments of environmental protection administration of the local People's governments at or above the county level shall conduct unified supervision and management of the environmental protection work within areas under their jurisdiction.

The state administrative department of marine affairs, the harbour superintendency administration, the fisheries administration and fishing harbour superintendency agencies, the environmental protection department of the armed forces and the administrative departments of public security, transportation, railways and civil aviation at various levels shall, in accordance with the provisions of relevant laws, conduct supervision and management of the prevention and control of environmental pollution. The competent administrative departments of land, minerals, forestry, agriculture and water conservancy of the People's governments at or above the county level shall, in accordance with the provisions of relevant laws, conduct supervision and management of the protection of natural resources.

Article 8 The People's government shall give awards to units and individuals that have made outstanding achievements in protecting and improving the environment.

\section{CHAPTER II SUPERVISION AND MANAGEMENT OF THE ENVIRONMENT}

Article 9 The competent department of environmental protection administration under the State Council shall establish the national standards for environment quality.

The People's governments of provinces, autonomous regions and municipalities directly under the Central Government may establish their local standards for environment quality for items not specified in the national standards for environment quality and shall report them to the competent department of environmental protection administration under the State Council for the record.

Article 10 The competent department of environmental protection administration under the State Council shall, in accordance with the national standards for environment quality and the country's economic and technological conditions, establish the national standards for the discharge of pollutants.

The People's governments of provinces, autonomous regions and municipalities directly under the Central Government may establish their local standards for the discharge of pollutants for items not specified in the 
national standards; with regard to items already specified in the national standards, they may set local standards which are more stringent than the national standards and report the same to the competent department of environmental protection administration under the State Council for the record.

Units that discharge pollutants in areas where the local standards for the discharge of pollutants have been established shall observe such local standards.

Article 11 The competent department of environmental protection administration under the State Council shall establish a monitoring system, formulate the monitoring norm and, in conjunction with relevant departments, organize a monitoring network and strengthen the management of environmental monitoring.

The competent departments of environmental protection administration under the State Council and governments of provinces, autonomous regions and municipalities directly under the Central Government shall regularly issue bulletins on environmental situations.

Article 12 The competent departments of environmental protection administration of the People's governments at or above the county level shall, in conjunction with relevant departments, make an investigation and an assessment of the environmental situation within areas under their jurisdiction, draw up plans for environmental protection which shall, subject to overall balancing by the department of planning, be submitted to the People's government at the same level for approval before implementation.

Article 13 Units constructing projects that cause pollution to the environment must observe the state provisions concerning environmental protection for such construction projects.

The environmental impact statement on a construction project must assess the pollution the projects is likely to produce and its impact on the environment and stipulate the preventive and curative measures; the statement shall, after initial examination by the authorities in charge of the construction project, be submitted by specified procedure to the competent department of environmental protection administration for approval. The department of planning shall not ratify the design plan descriptions of the construction project until after the environmental impact statement on the construction project is approved.

Article 14 The competent departments of environmental protection administration of the People's governments at or above the county level or other departments invested by law with power to conduct environmental supervision and management shall be empowered to make on site inspections of units under their jurisdiction that discharge pollutants. The units being inspected shall truthfully report the situation to them and provide them with the necessary information. The inspecting authorities shall keep confidential the technological know how and business secrets of the units inspected.

http://english.mep.gov.cn/Policies_Regulations/laws/environmental_laws/200710/t200... 2009-10-7 
Article 15 Work for the prevention and control of the environmental pollution and damage that involves various administrative areas shall be conducted by the relevant local People's governments through negotiation, or by decision of the people's government at a higher level through mediation.

\section{CHAPTER III PROTECTION AND IMPROVEMENT OF THE ENVIRONMENT}

Article 16 The local People's governments at various levels shall be responsible for the environment quality of areas under their jurisdiction and take measures to improve the environment quality.

Article 17 The People's governments at various levels shall take measures to protect regions representing various types of natural ecological systems, regions with a natural distribution of rare and endangered wild animals and plants, regions where major sources of water are conserved, geological structures of major scientific and cultural value, famous regions where karst caves and fossil deposits are distributed, traces of glaciers, volcanos and hot springs, traces of human history, and ancient and precious trees. Damage to the above shall be strictly forbidden.

Article 18 Within the scenic spots or historic sites, nature reserves and other zones that need special protection, as designated by the State Council, the relevant competent department under the State Council, and the People's governments of provinces, autonomous regions and municipalities directly under the Central Government, no industrial production installations that cause environmental pollution shall be built; other installations to be built in these areas must not exceed the prescribed standards for the discharge of pollutants. If the installations that have been built discharge more pollutants than those are specified by the prescribed discharge standards, such pollution shall be eliminated or controlled within a prescribed period of time.

Article 19 Measures must be taken to protect the ecological environment while natural resources are being developed or utilized.

Article 20 The People's governments at various levels shall provide better protection for the agricultural environment by preventing and controlling soil pollution, the desertification and alkalization of land, the impoverishment of soil, the deterioration of land into marshes, earth subsidence, the damage of vegetation, soil erosion, the drying up of sources of water, the extinction of species and the occurence and development of other ecological imbalances, by extending the scale of a comprehensive prevention and control of plant diseases and insect pests, and by promoting a rational application of chemical fertilizers, pesticides and plant growth hormone.

Article 21 The State Council and the People's governments at various levels in coastal areas shall provide better protection for the marine environment. The discharge of pollutants and the dumping of wastes into the seas, the construction of coastal projects, and the exploration and exploitation of offshore oil must be conducted in compliance with legal provisions so as to guard against the pollution and damage of the marine environment.

http://english.mep.gov.cn/Policies_Regulations/laws/environmental_laws/200710/t200... 2009-10-7 
Article 22 The targets and tasks for protecting and improving the environment shall be defined in urban planning.

Article 23 In urban and rural construction, vegetation, waters and the natural landscape shall be protected and attention paid to the construction of gardens, green land and historic sites and scenic spots in the cities in the light of the special features of the local natural environment.

\section{CHAPTER IV PREVENTION AND CONTROL OF ENVIRONMENTAL POLLUTION AND OTHER PUBLIC HAZARDS}

Article 24 Units that cause environmental pollution and other public hazards shall incorporate the work of environmental protection into their plans and establish a responsibility system for environmental protection, and must adopt effective measures to prevent and control the pollution and harms caused to the environment by waste gas, waste water, waste residues, dust, malodorous gases, radioactive substances, noise, vibration and electromagnetic radiation generated in the course of production, construction or other activities.

Article 25 For the technological transformation of newly built industrial enterprises and existing industrial enterprises, facilities and processes that effect a high rate of the utilization of resources and a low rate of the discharge of pollutants shall be used, along with economical and rational technology for the comprehensive utilization of waste materials and the treatment of pollutants.

Article 26 Installations for the prevention and control of pollution at a construction project must be designed, built and commissioned together with the principal part of the project. No permission shall be given for a construction project to be commissioned or used, until its installations for the prevention and control of pollution are examined and considered up to the standard by the competent department of environmental protection administration that examined and approved the environmental impact statement.

Installations for the prevention and control of pollution shall not be dismantled or left idle without authorization. If it is really necessary to dismantle such installations or leave them idle, prior approval shall be obtained from the competent department of environmental protection administration in the locality.

Article 27 Enterprises and institutions discharging pollutants must report to and register with the relevant authorities in accordance with the provisions of the competent department of environmental protection administration under the State Council.

Article 28 Enterprises and institutions discharging pollutants in excess of the prescribed national or local discharge standards shall pay a fee for excessive discharge according to state provisions and shall assume responsibility for eliminating and controlling the pollution. The provisions of the Law on Prevention and Control of Water Pollution shall be complied with where they are applicable.

http://english.mep.gov.cn/Policies_Regulations/laws/environmental_laws/200710/t200... 2009-10-7 
The income derived from the fee levied for the excessive discharge of pollutants must be used for the prevention and control of pollution and shall not be appropriated for other purposes. The specific measures thereof shall be prescribed by the State Council.

Article 29 If an enterprise or institution has caused severe environmental pollution, it shall be required to eliminate and control the pollution within a certain period of time.

For enterprises and institutions directly under the jurisdiction of the Central Government or the People's government of a province, an autonomous region, or a municipality directly under the Central Government, the decision on a deadline for the elimination or control of pollution shall be made by the People's government of the province, autonomous region and the municipality directly under the Central Government. For enterprises and institutions under the jurisdiction of a People's government at or below the city or county level, such decision shall be made by the People's government of the city or county. Such enterprises and institutions shall accomplish the elimination or control of pollution within the specified period of time.

Article 30 A ban shall be imposed on the importation of any technology or facility that fails to meet the requirements specified in the regulations of our country concerning environmental protection.

Article 31 Any unit that, as a result of an accident or any other exigency, has caused or threatens to cause an accident of pollution, must promptly take measures to prevent and control the pollution hazards, make the situation known to such units and inhabitants as are likely to be endangered by such hazards, report the case to the competent department of environmental protection administration of the locality and the departments concerned and accept their investigation and decision.

Enterprises and institutions that are likely to cause severe pollution accidents shall adopt measures for effective prevention.

Article 32 If the safety of the lives and property of inhabitants is endangered by severe environmental pollution, the competent department of environmental protection administration of the local People's government at or above the county level must promptly report to the local People's government. The People's government concerned shall take effective measures to remove or alleviate the hazard.

Article 33 The production, storage, transportation, sale and use of toxic chemicals and materials containing radioactive substances must comply with the relevant state provisions so as to prevent environmental pollution.

Article 34 No unit shall be permitted to transfer a production facility that causes severe pollution for use by a unit that is unable to prevent and control pollution.

http://english.mep.gov.cn/Policies_Regulations/laws/environmental_laws/200710/t200... 2009-10-7 


\section{CHAPTER V LEGAL LIABILITIES}

Article 35 Any violator of this Law shall, according to the circumstances of the case, be warned or fined by the competent department of environmental protection administration or another department invested by law with power to conduct environmental supervision and management for any of the following acts:

(1) refusing an on site inspection by the competent department of environmental protection administration or another department invested by law with power to conduct environmental supervision and management, or resorting to trickery and fraud while undergoing inspection;

(2) refusing to report or submitting a false report on items for which declaration is required by the competent department of environmental protection administration under the State Council;

(3) failing to pay, as provided for by the state, the fee for the excessive discharge of pollutants;

(4) importing technology or a facility that fails to meet the requirements specified in the state provisions concerning environmental protection; or

(5) transferring a production facility that causes severe pollution for use by a unit that is unable to prevent and control pollution.

Article 36 When a construction project is commissioned or put to use in circumstances where facilities for the prevention and control of pollution either have not been completed or fail to meet the requirements specified in state provisions, the competent department of environmental protection administration responsible for the approval of the environmental impact statement on the construction project shall order the suspension of its operations or use and may concurrently impose a fine.

Article 37 A unit which dismantles or leaves idle the installations for the prevention and control of pollution without prior approval by the competent department of environmental protection administration, thereby discharging pollutants in excess of the prescribed discharge standards, shall be ordered by the competent department of environmental protection administration to set up the installations or put them to use again, and shall concurrently be fined.

Article 38 An enterprise or institution which violates this Law, thereby causing an environmental pollution accident, shall be fined by the competent department of environmental protection administration or another department invested by law with power to conduct environmental supervision and management in accordance with the consequent damage; in a serious case, the persons responsible shall be subject to administrative 
sanction by the unit to which they belony or by the competent department of the government.

Article 39 An enterprise or institution that has failed to eliminate or control pollution by the deadline as required shall, as provided for by the state, pay a fee for excessive discharge; in addition, a fine may be imposed on it on the basis of the damage incurred, or the enterprise or institution may be ordered to suspend its operations or close down.

The fine as specified in the preceding paragraph shall be decided by the competent department of environmental protection administrations. An order for the suspension of operations or shut-down of an enterprise or institution shall be issued by the People's government that set the deadline for the elimination or control of pollution. An order for the suspension of operations or shut-down of an enterprise or institution directly under the jurisdiction of the Central Government shall be submitted to and approved by the State Council.

Article 40 A party refusing to accept the decision on administrative sanction may, within 15 days of receiving the notification on such a decision, apply for reconsideration to the department next higher to the authorities that imposed the sanction; if the party refuses to accept the decision of reconsideration, it may, within 15 days of receiving the reconsideration decision, bring a suit before a People's court. A party may also bring a suit directly before a people's court within 15 days of receiving the notification on the sanction. If, upon the expiration of this period, the party has not applied for reconsideration or has neither brought a suit before a People's court nor complied with the sanction, the authorities that imposed the sanction may apply to the People's court for compulsory enforcement.

Article 41 A unit that has caused an environmental pollution damage shall have the obligation to eliminate it and make compensation to the unit or individual that suffered direct losses.

A dispute over the liability to make compensation or the amount of compensation may, at the request of the parties, be settled by the competent department of environmental protection administration or another department invested by law with power to conduct environmental supervision and management. If a party refuses to accept the decision on the settlement, it may bring a suit before a people's court. The party may also directly bring a suit before the People's court.

If environmental pollution losses result solely from irresistible natural disasters which cannot be averted even after the prompt adoption of reasonable measures, the party concerned shall be exempted from liability.

Article 42 The limitation period for prosecution with respect to compensation for environmental pollution losses shall be three years, counted from the time when the party becomes aware of or should become aware of the pollution losses.

http://english.mep.gov.cn/Policies_Regulations/laws/environmental_laws/200710/t200... 2009-10-7 
Article 43 If a violation of this Law causes a serious environmental pollution accident, leading to the grave consequences of heavy losses of public or private property or human injuries or deaths of persons, the persons directly responsible for such an accident shall be investigated for criminal responsibility according to law.

Article 44 Whoever, in violation of this Law, causes damage to natural resources like land, forests, grasslands, water, minerals, fish, wild animals and wild plants shall bear legal liability in accordance with the provisions of relevant laws.

Article 45 Any person conducting supervision and management of environmental protection who abuses his power, neglects his duty or engages in malpractices for personal gains shall be given administrative sanction by the unit to which he belongs or the competent higher authorities; if his act constitutes a crime, he shall be investigated for criminal responsibility according to law.

\section{CHAPTER VI SUPPLEMENTARY PROVISIONS}

Article 46 If an international treaty regarding environmental protection concluded or acceded to by the People's Republic of China contains provisions differing from those contained in the laws of the People's Republic of China, the provisions of the international treaty shall apply, unless the provisions are ones on which the People's Republic of China has announced reservations.

Article 47 This Law shall enter into force on the date of promulgation. The Environmental Protection Law of the People's Republic of China (for Trial Implementation) shall be abrogated therefrom.

Source:

\section{【 Big Medium-sized Small】【Print】【Close】}

Sponsored by MEP, Address: No.115 Xizhimennei Nanxiaojie, Beijing (100035)

Telephone Numbers for Administrative Offices

http://english.mep.gov.cn/Policies_Regulations/laws/environmental_laws/200710/t200... 2009-10-7 